\title{
The determinants for the adoption of compost from household waste for crop production by farmers living nearby Yaoundé, Cameroon: descriptive and logit model approaches of analysis
}

\author{
Achille Jean JAZA FOLEFACK \\ Department of Agricultural Economics, University of Dschang, Cameroon. \\ E-mail: ajazafol@yahoo.fr; P.O. Box 31535 Yaoundé, Cameroon. \\ Tel: (237) 695844205
}

\begin{abstract}
This paper analyzes the factors influencing the utilization of compost from household waste by farmers living around Yaoundé-city, Cameroon. Both descriptive statistics and logit model are used to analyze the data collected from 108 farmers residing in villages surrounding the city. The descriptive results show that 14 factors mostly affect the compost adoption by farmers. These are gender of farmer, contact with extension agents, education, vegetables cultivation, salarial labour, compost efficacy, household size, managerial position, equipment value, membership in association, membership in credit system, use of mineral fertilizer, animal manure and other fertilizer types. These are mainly factors with positive coefficients and odds ratio higher than one in logit model. However, the percentage of non-compost adopters is higher than compost adopters for the remaining 7 factors (age of farmer, farm size, farm-to-city's distance, extra-agricultural occupation, animal husbandry practice, land property right, crops association or rotation practice). These latter 7 factors display negative coefficients and odds ratio lower than one in logit model. Hence, the government should popularize compost by reviewing disfavourable factors and by rewarding/subsidizing farmers using compost.
\end{abstract}

(C) 2015 International Formulae Group. All rights reserved.

Keywords: Adoption, compost users, logit model, non compost users, odds ratio.

\section{INTRODUCTION}

The management of urban household waste in Yaoundé, the capital city of Cameroon, became an acute problem since the early 1990s (Focarfe, 2005). Due to an inefficient collection, disposal and management system, the household wastes generated in this city heap up continuously provoking a dirty, unaesthetic environment, water pollution, bad odours causing air pollution and multiplication of flies that are diseases carriers (e.g. malaria, typhoid, diarrhoea, cholera, dysentery, etc.) (Jaza, 2005). However, composting those household wastes and distributing the processed compost for crop production in farms surrounding the city could help to avoid or reduce both waste management and soil degradation problems (Ndoumbé et al., 1995; Jaza, 2007).

According to Ngnikam (2000) and Ngnikam et al. (2005), with a Carbon to Nitrogen $(\mathrm{C} / \mathrm{N})$ ratio of 16 and its total 
organic matter content which is about $17.7 \%$ of dry matter, the compost of Yaoundé is suitable for restoring the soil fertility maintaining thereby the microbiological equilibrium of soils. Thus, this compost can conveniently be used as fertilizer for crop production. Another study by Jaza and Adamowski (2012) reveals that, if all of the Yaoundé's collected household waste were to be processed into compost (assuming 1 ton household waste creates 0.42 ton of compost), it would generate roughly 124,320 tons of compost annually (Kuete et al., 2003; Ngnikam et al., 2005). Given that Yaoundé's $6.8 \%$ annual population growth rate is accompanied by an increase in per capita food consumption, one can expect to see a higher output of household waste in the future (Kuete et al., 2003; Focarfe, 2005; World Bank, 2014). The rise in household waste should therefore result in a higher quantity of compost generated in the city. The compost could be readily used by local farmers to aid in crop production and fertilization; however the low demand for compost within the urban areas of Yaoundé has raised doubts regarding its profitability, thus resulting in low conversion rates.

Actually, small-scale composting activities already exist and about $32 \%$ of farmers living nearby Yaoundé currently utilize the resulting compost and animal manure to produce food and cash crops (Ministry of Agriculture, 2003; Jaza, 2009). This means that, in spite of land degradation problems or low organic matter content of their soil, more than $68 \%$ of farmers from this area are still reticent or have the doubt on the high efficacy, productivity or profitability of improving the yield of their crops by using the compost made from household waste (Jaza, 2009; Jaza and Adamowski, 2012). This latter group of farmers rather prefer using mineral fertilizer and other alternative or substituting fertilizers which are less costly, less voluminous/bulky, less labour demanding, less heavy or easier to transport, etc.
Recent studies (Nkamleu, 1996; Yecke, 2004; Jaza, 2005; Jaza, 2009; Jaza and Adamowski, 2012) analyzed whether or not it is profitable to produce crops by using the Yaoundé compost rather than mineral fertilizer. They concluded that, compost use is beneficial in areas within the $0-79 \mathrm{~km}$ radius to Yaoundé-centre and non-beneficial to zones located beyond the $80 \mathrm{~km}$ radius to the citycentre. In spite of the advertisement of produced compost within the most profitable $0-79 \mathrm{~km}$ radius to the city, the rate of its adoption in farms located in this zone is still very low (Ngnikam and Tanawa, 2002). Until now, most studies (Nkamleu, 1996; Yecke, 2004; Jaza, 2005; Ngnikam, 2005; Jaza, 2009; Jaza and Adamowski, 2012) have focused on the household waste valorization in farming, but without putting a special attention on the reasons of low rate of compost use in farms located closer to the city. Thus, this paper attempts to bridging this gap by analyzing the determinants of compost adoption by farmers producing food or cash crops in localities nearness Yaoundé.

\section{MATERIALS AND METHODS Field survey and data collection}

The field survey was conducted from January to May 2014 within the urban and peri-urban areas of the capital city of Yaoundé, Cameroon. Included in the survey were 15 other surrounding villages with similar soil and climatic conditions to each other. Administratively, all the selected villages belong to the Centre region of the country.

The Centre region was chosen because it contains Yaoundé (the capital city of Cameroon and the county-town of the region) which produces among the highest quantity (roughly 124,320 tons annually) of compost generated from household waste in the country; the ferrallitic nature of its soils which are very poor in organic matter; the availability of data and the large number of compost users practicing in this location (Kuete et al., 2003; Jaza, 2009). 
A total of 108 farmers (comprised of 52 compost users and 56 non-compost users) of the region were purposely selected for the survey. The selected compost users were farmers using compost as main fertilizer whereas the non-compost users were those using mineral fertilizer as major fertilizer. Using a prepared questionnaire and interview schedule, cross-sectional primary data of the cropping season 2013/2014 were collected from the two categories of farmers (compost users and non-compost users).

The data collected from each farmer were precisely the: age, gender, farm size/land area cultivated by the farmer, farmer's membership in a peasant's association, farmer's membership in a rural credit system, farm-to-house's distance, practice of extraagricultural occupation, frequency of contact with extension agents, level of education of farmer, practice of animal husbandry, cultivation of vegetables, ownership of land property right, use of salarial labour, psychological opinion on compost efficacy, previous use of mineral fertilizer, animal manure, and other fertilizer types, practice of crops association or rotation, occupation of managerial position, size of household, value of agricultural equipment, etc.

\section{Data analysis}

The data collected in this paper are analyzed by using both the descriptive statistics and logit model thanks to the version 21.0 of the software program SPSS (Statistical Package for Social Sciences) (SPSS, 2014).

Theoretical framework and justification of the use of logit model

Generally, a study which aims at analyzing the influence of several predictors upon one dependant qualitative variable (with two categories of responses such as "adoption" or "non-adoption" of compost) does not generally fit with a linear probability model because of its weaknesses (heteroskedastic error problem, non-normally distributed error, prediction of probabilities' values outside the [0-1] range). Thus for such study, the econometrics literature suggests two alternative models which are namely the logit and probit models computed with the method of Maximum Likelihood Estimation (MLE) (Gujarati, 1995; Terrell, 1999; Wooldridge, 2009; SPSS, 2014).

In this study, the logit model is more convenient because we use a low sample size $(\mathrm{N}=108)$ which enables us to compute the probabilities necessary for interpreting each explanatory variable/predictor. Furthermore, one of the advantages of using a logit model is that, the explanatory variables could be a mix of continuous and qualitative variables or one of the two types (continuous or qualitative). The data of this paper contain both the continuous and qualitative predictors/ explanatory variables and hence they can properly be used in logit model for analyzing the determinants of compost adoption by farmers producing food or cash crops (Gujarati, 1995; Terrell, 1999; Wooldridge, 2009; SPSS, 2014).

In the logit model, we will be predicting the logit, that is, the natural log of the odds ratio of having made one or the other decision ("adoption" or "non-adoption" of compost). By denoting $\mathrm{P}$ as the probability of making such decision from a predictor $\mathrm{X}$, the mathematical formulation of the logit model is expressed in Equation (1) as:

$$
Y=\operatorname{Logit}(P)=\operatorname{Ln}\left(\frac{P}{1-P}\right)=\alpha+\beta X
$$

Or equivalently, we can derive $\mathrm{P}$ from Equation (1) such as:

$$
P=\frac{1}{1+\left[E x p^{-(\alpha+\beta X)}\right]}
$$

Where: P: is the predicted probability of the occurrence of event ("adoption" of compost); 1-P: is the predicted probability of non-occurrence of event ("non-adoption" of compost); $\mathbf{X}$ : is the explanatory variable representing different factors influencing the farmer's decision to adopt compost; $\mathbf{Y}$ : is the dependant variable designating whether a farmer is a compost user or a non-compost user; Exp: is the exponential function with 
natural logarithmic base; $\boldsymbol{\alpha}$ : is the intercept term; $\boldsymbol{\beta}$ : is the slope coefficient.

The left-hand-side of the above Equation (1) is known as the log odds ratio and the model is known as the logit model (Gujarati, 1995; Wooldridge, 2009).

Specification of variables integrated in the logit model

This paper analyzes the factors which are determinants to the farmer's decision on whether or not to adopt compost. As there are several factors, the logit model considers them as covariates or explanatory variables. Hence, by extending Equation (1) to a multivariate case in which there are 21 covariates or explanatory variables $\left(\mathrm{X}_{1}, \mathrm{X}_{2}, \ldots \ldots \ldots, \mathrm{X}_{21}\right)$ like in this study, we obtain Equation (3) expressed as follows:

$$
Y=\operatorname{Logit}(P)=\operatorname{Ln}\left(\frac{P}{1-P}\right)=\alpha+\beta_{1} X_{1}+\beta_{2} X_{2}+\ldots \ldots+\beta_{21} X_{21}
$$

From Equation (3), we can compute the probability $\mathrm{P}$ by taking the exponential (Exp) in both sides of the expression. Hence, the predicted probability value $\mathrm{P}$ of adopting compost is expressed as:

$$
P=\frac{1}{1+\left[\operatorname{Exp}^{-\left(\alpha+\beta_{1} X_{1}+\beta_{2} X_{2}+\ldots \ldots . . \beta_{21} X_{21}\right)}\right]}
$$

Where: Y: Farmer group (with $1=$ compost users, $0=$ non-compost users); $\mathbf{X}_{\mathbf{1}}$ : Age of farmer (in years); $\mathbf{X}_{\mathbf{2}}$ : Gender of farmer (with $1=$ male, $0=$ female); $\mathbf{X}_{\mathbf{3}}$ : Farm size/land area cultivated by the farmer (in ha); $\mathbf{X}_{\mathbf{4}}$ : Farmer's membership in a peasant's association (with $1=$ yes, $0=$ no); $\mathbf{X}_{\mathbf{5}}$ : Farmer's membership in a rural credit system (with 1=yes, 0=no); $\mathbf{X}_{\mathbf{6}}$ : Farm-to-city's distance (in $\mathrm{km}) ; \quad \mathbf{X}_{7}$ : Practice of extra-agricultural occupation (with $1=y e s, 0=n o$ ); $\mathbf{X}_{\mathbf{8}}$ : Frequency of contact with extension agents (per cropping year); $\mathbf{X}_{\mathbf{9}}$ : Level of education of farmers (with $0=$ illiterate, $1=$ primary school, $2=$ secondary school, 3=university); $\mathbf{X}_{\mathbf{1 0}}$ : Practice of animal husbandry (with $1=$ yes, $0=$ no); $\quad \mathbf{X}_{\mathbf{1 1}}$ : Cultivation of vegetables (with $1=$ yes, $0=$ no); $\mathbf{X}_{\mathbf{1 2}}$ : Ownership of land property right (with $1=$ yes/own land, $0=$ no/rent land); $\mathbf{X}_{\mathbf{1 3}}$ : Use of salarial labour (with $1=y e s, \quad 0=$ no); $\mathbf{X}_{\mathbf{1 4}}$ : Psychological opinion on compost efficacy ( 0 =disfavourable, $1=$ neutral, 2 =favourable); $\mathbf{X}_{15}$ : Previous use of mineral fertilizer (with 1=yes, $0=$ no); $\mathbf{X}_{\mathbf{1 6}}$ : Previous use of animal manure (with $1=y e s, 0=$ no); $\mathbf{X}_{17}$ : Previous use of other fertilizer types (with $1=y e s, 0=$ no); $\mathbf{X}_{\mathbf{1 8}}$ : Practice of crops' rotation or association (with $1=$ yes, $0=$ no); $\mathbf{X}_{19}$ : Occupation of managerial position (with $1=$ yes, $0=$ no); $\mathbf{X}_{\mathbf{2 0}}$ : Size of the farmer's household (in number of persons); $\mathbf{X}_{\mathbf{2 1}}$ : Value of agricultural equipment (in FCFA); $\boldsymbol{\alpha}$ : Intercept term; $\boldsymbol{\beta}_{\mathbf{1}}, \boldsymbol{\beta}_{\mathbf{2}}, \ldots . ., \boldsymbol{\beta}_{\mathbf{2}}$ (termed as $\boldsymbol{\beta}_{\mathbf{k}}$ ) are respectively the slope coefficients of the explanatory variables $\mathbf{X}_{\mathbf{1}}$, $\mathbf{X}_{2}, \ldots . ., \mathbf{X}_{\mathbf{2 1}}$ (termed as $\mathbf{X}_{\mathbf{k}}$ ), to be estimated in SPSS software.

Equation (4) represents what is known as the cumulative logistic probability function. By generalizing it to each observation denoted by an $\mathrm{i}$ index, $\mathrm{P}_{\mathrm{i}}$ is the probability that farmer $\mathrm{i}$ adopts compost whereas $1-P_{i}$ represents the probability that farmer $\mathrm{i}$ does not adopt compost. From this notation, the logit is simply the natural log of the odds ratio $\frac{P_{i}}{1-P_{i}}$ in favour of adopting compost by farmer i, that is, the ratio of the probability that farmer $i$ will adopt compost to the probability that he will not adopt this input (see Equation 3).

The exponentials of the slope coefficients $\beta_{\mathrm{k}}$ associated to the explanatory variables are interpreted as the Odds Ratio (OR) of adopting the compost (or of occurrence of the event) for each increase in the explanatory variable. In general, since the OR of logit model are just the exponentials of estimated coefficients $\beta_{\mathrm{k}}$, the positive coefficients will usually display an OR greater than one $(O R>1)$ whereas the negative coefficients will generally indicate an OR lower than one $(\mathrm{OR}<1)$. Usually, the expression 1/Exp(B) designates the inverse OR which is computed in order to facilitate the interpretation of the variables with negative coefficients (Gujarati, 1995; Terrell, 1999; Wooldridge, 2009). 


\section{RESULTS}

Field survey findings

Descriptive farmers' responses on different factors influencing the compost adoption

The factors described in Table 1 are differently interpreted depending whether the farmers' responses are discrete or continuous in nature. The factors with continuous responses are the: age of farmer, farm size, farm-to-city's distance, frequency of contact with extension agents, size of farmer's household and value of agricultural equipment.

By considering the age of farmers (Table 1), its computed mean indicates that the selected farmers have an average age of 39.56 years with a standard deviation of 9.708 years. The less-aged farmer is 19 years old whereas the most-aged farmer is 70 years old. The standard deviation of 9.708 which is quite distant from the computed mean of 39.56 shows that, the age of most farmers oscillate within the range between 29.852 or 49.268 years. Similar interpretations can be done for the rest of continuous variables (Table 1).

The factors with discrete responses in Table 1 are the: gender of farmer, farmer's membership in a peasant's association, farmer's membership in a rural credit system, practice of extra-agricultural occupation, level of education of farmer, practice of animal husbandry, cultivation of vegetables, ownership of land property right, use of salarial labour, psychological opinion on compost efficacy, previous use of mineral fertilizer, previous use of animal manure, previous use of other fertilizer types, practice of crops' association or rotation, occupation of managerial position, and size of farmer's household. By interpreting for example the gender of farmer (coded as 1 for male and 0 for female), its computed mean is 0.63 which indicates that more than half (that is about $2 / 3$ ) of selected farmers are male persons. Its standard deviation of 0.485 is distant from the computed mean, implying a large deviation of observed values from the mean; possibly because of the discrete nature of all responses (coded with either 1 or 0 values). Similar interpretations can be done for all other qualitative variables (Table 1).

Compost adoption rate per response category and counted number of adopters

In Table 2, by comparing the adoption to non-adoption rates for factors with binary responses ("yes" or "no"), the farmers that are members of peasants association have a high compost adoption rate as compared to farmers who are non-members of such association. By taking another example on the gender of farmer, the computed adoption rate for this factor indicates that, male farmers tend to adopt most the compost as compared to female farmers. Out of a total number of 68 male farmers which were interviewed in the study area, a proportion of $50 \%$ of them (that is, a frequency of 34) are compost adopters whereas $47.5 \%$ from the 40 female farmers are compost users. In total, from all the 108 selected farmers, a proportion of $31.48 \%$ of male are compost users as compared to only $17.59 \%$ for the female category (Table 2). Similarly, the percentage of compost adopters is higher than non-compost adopters for factors such as the membership in rural credit system, cultivation of vegetables, use of salarial labour, previous use of mineral fertilizer, previous use of animal manure, previous use of other fertilizer types, and occupation of managerial position. In opposite, the percentage of non-compost adopters is higher than compost adopters for factors such as the extra agricultural occupation, practice of animal husbandry, ownership of land property right, practice of crops association or rotation (Table 2). The interpretation is similar for factors with continuous responses such as the age of farmer, farm size, farm-to-city's distance, frequency of contact with extension agents, size of farmer's household, value of agricultural equipment (Table 2).

The computed figures in Table 2 suggest that the higher the age of the farmers, the lower their ability to adopt compost. More precisely for those farmers beyond the age of 
35 years (old farmers), the compost adoption rate is $28.13 \%$ as compared to $79.55 \%$ of adoption rate for young farmers $(\leq 35$ years old) (Table 2).

By looking at a factor such as the farmto-city's distance, Table 2 indicates that the rate of compost adoption is lower for longdistant farms $(49.45 \%)$ as compared to shortdistant farms $(47.06 \%)$. Similarly, the farms with large parcels of land have the high compost adoption rate $(75.00 \%)$ as compared to the farms with small surface of land area (43.18\%). Likewise, households with large number of persons have the high adoption rate $(80.56 \%)$ as compared to the households of small size $(33.33 \%)$. The Table also shows that farmers with a high frequency of contact with extension agents adopt more compost (50\% of them) as compared to farmers with a low frequency of contact with extension agents (48.89\% of them). Similarly, rich farmers owning agricultural equipments of high value (>100.000 FCFA) record a high percentage of compost adoption than poor farmers with agricultural equipments of low value $(\leq 100.000$ FCFA $)$. In Table 2 , the adoption rate is $77.78 \%$ and $34.72 \%$ for farmers with high and low values of agricultural equipments, respectively.

Considering a factor with multiple responses such as the level of education of farmers, the adoption rate of compost differs per category of response. Table 2 results suggest that the more the farmers are educated, the higher is their aptitude to adopt the compost. More precisely, the highest adoption rate is observed for those farmers who have reached at least the secondary school or university level $(71.43 \%$ or $85.00 \%$, respectively) followed by those farmers with primary education $(22.22 \%)$ and lastly by the illiterates' farmers (11.76\%). For all farmers, the computed figures show the same trend of highest-adoption rate in function with the level of farmers' education, that is, an increase from $1.85 \%$ to $7.47 \%$, and $23.15 \%$ as farmers' education level change from illiterate to primary and secondary education, respectively. Similar interpretations can be done for the other qualitative variable with multi-category responses such as the psychological opinion on compost efficacy (Table 2).

\section{Results of the estimated coefficients and odd ratios of logit model}

Table 3 shows the results of the logit model for assessing the factors influencing the compost adoption by farmers in the study area. The overall goodness-of-fit measured by the significance of the Chi-square statistic in the Omnibus tests of model coefficients is high $\left(\chi^{2}=102.459\right.$, significant at $1 \%$ level $)$. The percentage of model's correct prediction is good (78.33\%). The Hosmer and Lemeshow test shows that the model adequately fits the data (the test was not significant at $5 \%$ level with $\alpha=0.304$, thus, the null hypothesis could not be rejected). Besides, most of the explanatory variables have the expected signs. The estimated coefficients and Odd Ratios (OR) and/or inverse OR of each explanatory variable are separately interpreted as follows (Table 3):

$X_{1}=$ age of farmer (in years): The coefficient of the age variable is significant at $10 \%$ level and its negative sign indicates that, the old farmers are less favourable to compost adoption as compared to the young category of farmers. In other words, young people would like to adopt compost as compared to old persons who are more reticent to use this input. The OR of this age variable is 0.943 (that is, less than one) which implies that, for each additional year in the age of the farmer, the probability of non-adopting the compost input increases by $1 / 0.943=1.060$ (Table 3 ).

$$
X_{2}=\text { Gender of farmer (with } 1=\text { male; }
$$
$0=$ female): This variable has a positive coefficient (significant at 5\% level) which implies that, male farmers are more likely to adopt compost as compared to female farmers. For this variable, the model suggests an OR of 2.474 which indicates that, male farmers are 2.474 times more likely of adopting compost as female farmers. Alternatively, this can be interpreted as indicating that the probability of adopting compost in the case of a male farmer 
is over twice as great as in the case of a female farmer (Table 3).

$X_{3}=$ Farm size/land area cultivated by the farmer (in ha): This variable has a significant coefficient (at $1 \%$ level) with negative sign which indicates that, farmers with large land area are less likely to adopt compost as compared to farmers with small parcels of cultivated land. This assertion is confirmed in Table 3, where the OR for this variable is 0.824 (that is, less than one) implying that, for each additional hectare of land area cultivated by the farmer, the probability of non-adopting the compost input increases by $1 / 0.824=1.214$ (Table 3).

$X_{4}=$ Farmer's membership in a peasant's association (with $1=y e s ; 0=n o$ ): The coefficient of this variable is significant (at $10 \%$ level) with positive sign, indicating that farmers belonging to a peasants association are more likely of adopting compost than those farmers without adherence to any group. More explicitly, this coefficient has an OR of 2.012 indicating that, farmers who are members of a peasant association are at a 2.012 greater probability of adopting compost than those belonging to none peasant association (Table 3). Alternatively, this can be interpreted as indicating that the probability of adopting compost of a farmer who is member in a peasant association is over twice as great as in the case of a farmer non-member in a peasant association (Table 3).

$X_{5}=$ Farmer's membership in a rural credit system (with l=yes; $0=n o$ ): The significant (at $10 \%$ level) positive coefficient of this variable indicates that, farmers who are member in a rural credit system are more likely to adopt the compost input than those farmers who are not affiliated in a banking system in rural areas. The OR of this variable is 1.780 indicating that, by adhering into a rural credit system, farmers are at a 1.780 times more likely of adopting compost than those without any membership into a rural credit system. Alternatively, this can be interpreted as indicating that the probability of adopting compost for a farmer-member in a rural credit system is over than one and half times as great as in the case of a farmer nonmember in a rural credit system (Table 3 ).

$X_{6}=$ Farm-to-city's distance (in $\mathrm{km}$ ): The coefficient of this variable is significant at $5 \%$ level and its negative sign indicates that farmers living further away to the city-centre are less likely to adopt compost than farmers living closer to the city-centre where compost is made. This is confirmed by the inverse OR of 1.359 , which indicates that, for every one kilometer $(\mathrm{km})$ increase in the farm-to-city's distance, a farmer is $35.9 \%$ less likely to adopt compost (Table 3 ).

$X_{7}=$ Practice of extra-agricultural occupation (with $1=y e s ; 0=n o$ ): This variable has a negative coefficient (significant at $10 \%$ level) which implies that, farmers practicing extra-agricultural occupation are less likely to adopt compost as compared to those who are fully involved in agricultural occupation. An OR of 0.352 (less than one) for this variable is a proof that, farmers without extra-agricultural occupation are at a $1 / 0.352=2.838$ greater probability of adopting compost than those who are fully engaged in agricultural occupation. Alternatively, this can be interpreted as indicating that the probability of adopting compost in the case of a farmer working only in agricultural sector is about three times as great as in the case of a farmer working in other additional sector, apart from agriculture (Table 3 ).

$X_{8}=$ Frequency of contact with extension agents (per cropping year): The coefficient this variable is significant at $5 \%$ level and its positive sign indicates that farmers with high frequency of contact with extension agents are more favourable to compost adoption as compared those farmers with lower frequency of contact with extension agents. In other words, farmers are regularly sensitized by extension agents are more likely to adopt compost as compared to those receiving none compost advertisement. The variable's OR of 1.518 proves that, for each additional contact of an extension agent with the farmer, the probability that this farmer would adopt compost increases by 1.518 (Table 3 ). 
$X_{9}=$ Level of education of farmers (with $0=$ illiterate; $1=$ primary school; $2=$ secondary school; 3=university): The computed coefficients of this variable indicate that farmers with a maximum education attainment of at least the secondary school have significantly positive likelihood of compost adoption, whereas lower educational levels of farmers are not significant in determining compost adoption. For this reason, those farmers who attained university level have the highest OR followed by those of secondary and primary school, confirming that the more a farmer is educated, the more probable he would adopt compost (Table 3 ).

$X_{10}=$ Practice of animal husbandry (with $1=$ yes; $0=n o)$ : This variable has a negative coefficient (significant at $10 \%$ level) which implies that, farmers practicing animal husbandry are less likely to adopt compost as compared to this category of farmers are fully specialized in crop production. The OR of 0.848 (less than one) for this variable is an indication that, farmers practicing none livestock activity are at a $1 / 0.848=1.179$ greater probability of adopting compost than those who practice livestock as a complementary activity to crop production. Alternatively, this can be interpreted as indicating that the probability of adopting compost in the case of a farmer practicing animal husbandry is 1.179 greater than a farmer who does not practice animal husbandry (Table 3).

$X_{1 I}=$ Cultivation of vegetables (with $l=y e s ; 0=n o$ ): This variable has a positive coefficient (significant at 5\% level) which implies that, farmers cultivating mainly the vegetables are more likely to adopt compost as compared to those farmers specialized in the cash and other food crops production. The derived OR of 1.347 for this variable indicates that farmers specialized in the production of vegetables are at a 1.347 greater probability of adopting compost than those with cash or other food crops as specialty. Alternatively, this can be interpreted as indicating that the probability of adopting compost in the case of farmers producing the vegetables is 1.347 greater than in the case of cash crops producers (Table 3 ).

$X_{12}=$ Ownership of land property right (with $1=y e s / o w n e d ~ l a n d ; 0=n o / r e n t e d ~ l a n d):$ This variable has a negative coefficient (significant at $10 \%$ level) which implies that farmers owners of their land are less likely to adopt compost as compared to those farmers who are land renters. The OR of 0.517 (less than one) for this variable indicates that farmers non-owners of their land are at a $1 / 0.517=1.933$ greater probability of adopting compost than those owners of their land. Alternatively, this can be interpreted as indicating that the probability of adopting compost in the case of a farmer with temporal land property right (land renters) is about two times as great as in the case of a farmer with permanent land property right (land owners) (Table 3).

$X_{13}=$ Use of salarial labour (with $1=y e s$; $0=n o$ ): This variable has a positive coefficient (significant at $1 \%$ level) which implies that, farmers using salarial labour are more likely to adopt compost as compared to the category of farmers employing non-salarial/familial labour. With an OR of 2.939 for this variable, one can say that farmers employing salarial workers are at a 2.939 greater probability of adopting compost than those farmers working with the members of their family. Alternatively, this can be interpreted as indicating that the probability of adopting compost in the case of farmers employing salarial labour is 2.939 greater than in the case of farmers with familial labour (Table 3).

$X_{14}=$ Psychological opinion on compost efficacy (with $0=$ disfavourable; $1=$ neutral; $2=$ favourable): The computed coefficients of this variable indicate that farmers with favourable opinion on compost efficacy are more likely to adopt compost (Table 3). More precisely, farmers with a favourable opinion on compost efficacy have significantly positive likelihood of compost adoption, whereas neutral farmers as well as farmers with disfavourable opinion on compost efficacy are not significant in determining compost adoption. For this reason, those 
farmers with favourable opinion on compost efficacy have the highest OR followed by those with neutral and disfavourable opinion, confirming that the psychological opinion on compost efficacy is determinant to the farmer's ability to adopt compost (Table 3).

$X_{15}=$ Previous use of mineral fertilizer (with $1=y e s ; 0=n o$ ): This variable has a positive coefficient (significant at $1 \%$ level) which implies that farmers with previous mineral fertilizer utilization are more likely to adopt compost as compared to those farmers who never use mineral fertilizer in the past. The model suggests an OR of 1.471 for this variable which indicates that, farmers with previous fertilizer experience are at a 1.471 greater probability of adopting compost than those with less experience in fertilizer utilization. Alternatively, this can be interpreted as indicating that the predicted odds for farmers who previously used mineral fertilizer are 1.471 times the odds for those farmers who never experienced the mineral fertilizer utilization (Table 3).

$X_{16}=$ Previous use of animal manure (with $1=y e s ; 0=n o$ ): This variable has a positive coefficient (significant at $1 \%$ level) which implies that farmers who previously experienced the utilization of animal manure are more likely to adopt compost as compared to those farmers who never used animal manure in the past. An OR of 1.387 for this variable is an indication that, farmers with previous fertilizer experience are at a 1.387 greater probability of adopting compost than those with less experience in fertilizer utilization. Alternatively, this can be interpreted as indicating that the predicted odds for farmers who previously used animal manure are 1.387 times the odds for those farmers who never experienced the animal manure utilization (Table 3).

$X_{17}=$ Previous use of other fertilizer types (with $1=y e s ; 0=n o$ ): This variable has a positive coefficient (significant at $10 \%$ level) which implies that farmers with previous fertilization experience are more likely to adopt compost as compared to those farmers who never use fertilizer in the past. The computed OR of 1.376 for this variable indicates that, farmers who already used fertilizer in the past are at a 1.376 greater probability of adopting compost than those farmers with none fertilization experience. Alternatively, this can be interpreted as indicating that the probability of adopting compost is 1.376 times greater for farmers with previous fertilization experience than non-experienced farmers in fertilization (Table 3).

$X_{18}=$ Practice of crops' association or rotation (with $1=y e s ; 0=n o$ ): This variable has a negative coefficient (significant at $10 \%$ level) which implies that, farmers who practice mono-cropping are more likely to adopt compost as compared to those farmers who cultivate several crops in association or rotation. With an OR of 0.804 (less than one) for this variable, the interpretation is that, farms without crops association or rotation are at a $1 / 0.804=1.244$ greater probability of adopting compost than those practicing crops association or rotation. Alternatively, this can be interpreted as indicating that the odds of a farmer who does not practice crops' association or rotation are $24.4 \%$ higher than the odds of a farmer with an experience in crops' association or rotation (Table 3 ).

$X_{19}=$ Occupation of managerial position (with $1=y e s ; 0=n o$ ): This variable has a positive coefficient (significant at $10 \%$ level) which implies that farmers occupying a managerial position are more likely to adopt compost as compared to those farmers without any managerial position. More precisely, the model suggests an OR of 3.499 for this variable which indicates that, farmers with managerial position are at a 3.499 greater probability of adopting compost than those farmers holding none position of responsibility. Alternatively, this can be interpreted as indicating that, an appointment of a farmer at any leading position increases the odds of adopting the compost input by a factor of 3.499 (Table 3).

$X_{20}=$ Size of the farmer's household (in number of persons): The coefficient of the household's size variable is significant at $1 \%$ 
level and its positive sign indicates that a farmer with large household size is more favourable to compost adoption as compared to a farmer with small household size. In other words, farmers with low number of children and wives are reticent compost adoption as compared to farmers with households with high number of children and wives. The OR of 1.075 for this variable is an indication that for each additional person in the size of the farmer's household, the probability of adopting compost increases by 1.075 (Table $3)$.

$X_{21}=$ Value of agricultural equipment (in FCFA): The coefficient of the value of agricultural equipment is significant at $1 \%$ level and its positive sign indicates that, farmers with agricultural equipment of high value are more favourable to compost adoption as compared to farmers with agricultural equipment of low value. In other words, farmers who have none or less agricultural equipment (poor farmers) are reticent compost adoption as compared to farmers with highly modernized agricultural equipment (rich farmers). The OR of 2.022 for this variable is an indication that, for each additional value in the agricultural equipment owned by the farmer, the probability of adopting compost increases by 2.022 (Table $3)$.

Table 1: Distribution of responses from factors used to assess the compost adoption by farmers in the study area, year $2014(\mathrm{~N}=108)$.

\begin{tabular}{lcccc}
\hline Factor/Variable & Min & Max & Mean & $\begin{array}{c}\text { Standard } \\
\text { Deviation }\end{array}$ \\
\hline Farmer group (1=compost users; 0=non-compost users) & 0 & 1 & 0.49 & 0.50 \\
Age of farmer (years) & 19 & 70 & 39.56 & 9.71 \\
Gender of farmer (0/1) & 0 & 1 & 0.63 & 0.48 \\
Farm size/land area cultivated by the farmer (ha) & 0.03 & 1 & 0.33 & 0.22 \\
Farmer's membership in a peasant association (0/1) & 0 & 1 & 0.57 & 0.48 \\
Farmer's membership in a rural credit system (0/1) & 0 & 1 & 0.63 & 0.50 \\
Farm-to-city's distance (km) & 4 & 100 & 47.55 & 28.66 \\
Practice of extra-agricultural occupation (0/1) & 0 & 1 & 0.28 & 0.50 \\
Frequency of contact with extension agents (per year) & 0 & 11 & 2.96 & 3.08 \\
Level of education of farmers (0/1/2/3) & 0 & 3 & 1.54 & 0.97 \\
Practice of animal husbandry (0/1) & 0 & 1 & 0.45 & 0.50 \\
Cultivation of vegetables (0/1) & 0 & 1 & 0.69 & 0.47 \\
Ownership of land property right (0/1) & 0 & 1 & 0.37 & 0.50 \\
Use of salarial labour (0/1) & 0 & 1 & 0.58 & 0.50 \\
Psychological opinion on compost efficacy (0/1/2) & 0 & 2 & 0.99 & 0.88 \\
Previous use of mineral fertilizer (0/1) & 0 & 1 & 0.52 & 0.50 \\
Previous use of animal manure (0/1) & 0 & 1 & 0.59 & 0.50 \\
Previous use of other fertilizer types (0/1) & 0 & 1 & 0.57 & 0.50 \\
Practice of crops association or rotation (0/1) & 0 & 1 & 0.45 & 0.50 \\
Occupation of managerial position (0/1) & 0 & 1 & 0.56 & 0.50 \\
Size of the farmer's household (number of persons) & 1 & 25 & 8.27 & 5.77 \\
Value of agricultural equipment (FCFA) & 19,500 & $1,119,300$ & 94,174 & 107,886 \\
\hline In this Table, the figures in parentheses represent the codes of discrete variables as used by SPSS for each category of \\
responses. For example, the gender of farmer (0/1) means that: 0=female farmer and 1=male farmer, and so on... \\
Max = Maximum; Min= Maximum. & & & &
\end{tabular}




\section{A. J. JAZA FOLEFACK / Int. J. Biol. Chem. Sci. 9(1): 308-328, 2015}

Table 2: Counted number of adopters and adoption rate of compost per category of response from each factor influencing the farmer's decision, year 2014 (N=108).

\begin{tabular}{|c|c|c|c|c|c|}
\hline \multirow[t]{2}{*}{ Factor/Variable } & \multirow[t]{2}{*}{ Category of response } & \multirow{2}{*}{$\begin{array}{c}\text { Total number of farmers } \\
\text { interviewed in category } \\
\left(N^{\prime}\right)\end{array}$} & \multirow{2}{*}{$\begin{array}{l}\text { Counted number of } \\
\text { adopters: Frequency } \\
\text { (f) }\end{array}$} & \multicolumn{2}{|c|}{$\begin{array}{c}\text { Adoption rate of compost } \\
(\%)\end{array}$} \\
\hline & & & & Within category & From all farmers \\
\hline & $>35$ Years (old) & 64 & 18 & 28.13 & 16.67 \\
\hline Age of farmer & $\leq 35$ Years (young) & 44 & 35 & 79.55 & 32.41 \\
\hline \multirow[t]{2}{*}{ Gender of farmer } & Male & 68 & 34 & 50.00 & 31.48 \\
\hline & Female & 40 & 19 & 47.50 & 17.59 \\
\hline \multirow{2}{*}{$\begin{array}{l}\text { Farm size/land area cultivated by } \\
\text { farmer }\end{array}$} & $>0.5$ ha (large) & 20 & 15 & 75.00 & 13.89 \\
\hline & $\leq 0.5$ ha (small) & 88 & 38 & 43.18 & 35.19 \\
\hline \multirow{2}{*}{$\begin{array}{l}\text { Membership to peasant } \\
\text { association }\end{array}$} & Yes & 40 & 32 & 80.00 & 29.63 \\
\hline & No & 68 & 30 & 44.12 & 27.78 \\
\hline \multirow[t]{2}{*}{ Membership to rural credit system } & Yes & 46 & 31 & 67.39 & 28.70 \\
\hline & No & 62 & 22 & 35.48 & 20.37 \\
\hline \multirow[t]{2}{*}{ Farm-to-city's distance } & $>80 \mathrm{~km}($ far $)$ & 17 & 8 & 47.06 & 7.41 \\
\hline & $\leq 80 \mathrm{~km}($ close $)$ & 91 & 45 & 49.45 & 41.67 \\
\hline \multirow[t]{2}{*}{ Extra agricultural occupation } & Yes & 54 & 14 & 25.93 & 12.96 \\
\hline & No & 54 & 39 & 72.22 & 36.11 \\
\hline \multirow{2}{*}{$\begin{array}{l}\text { Frequency of contact with extension } \\
\text { agents }\end{array}$} & $>6$ per year & 18 & 9 & 50.00 & 8.33 \\
\hline & $\leq 6$ per year & 90 & 44 & 48.89 & 40.74 \\
\hline \multirow[t]{4}{*}{ Level of education of farmer } & Illiterate & 17 & 2 & 11.76 & 1.85 \\
\hline & Primary school & 36 & 8 & 22.22 & 7.41 \\
\hline & Secondary school & 35 & 25 & 71.43 & 23.15 \\
\hline & University & 20 & 17 & 85.00 & 15.74 \\
\hline \multirow[t]{2}{*}{ Practice of animal husbandry } & Yes & 49 & 16 & 32.65 & 14.81 \\
\hline & No & 59 & 37 & 62.71 & 34.26 \\
\hline Cultivation of vegetables & Yes & 74 & 44 & 59.46 & 40.74 \\
\hline
\end{tabular}


A. J. JAZA FOLEFACK / Int. J. Biol. Chem. Sci. 9(1): 308-328, 2015

\begin{tabular}{|c|c|c|c|c|c|}
\hline & No & 34 & 9 & 26.47 & 8.33 \\
\hline \multirow{2}{*}{ Ownership of land property right } & Yes (owned land) & 54 & 16 & 29.63 & 14.81 \\
\hline & No (rented land) & 54 & 37 & 68.52 & 34.26 \\
\hline \multirow{2}{*}{ Use of salarial labour } & Yes & 52 & 36 & 69.23 & 33.33 \\
\hline & No & 56 & 17 & 30.36 & 15.74 \\
\hline \multirow{3}{*}{$\begin{array}{l}\text { Psychological opinion on compost } \\
\text { efficacy }\end{array}$} & Disfavourable & 42 & 8 & 19.05 & 7.41 \\
\hline & Neutral & 25 & 13 & 52.00 & 12.04 \\
\hline & Favourable & 41 & 32 & 78.05 & 29.63 \\
\hline \multirow[t]{2}{*}{ Previous use of mineral fertilizer } & Yes & 56 & 41 & 73.21 & 37.96 \\
\hline & No & 52 & 12 & 23.08 & 11.11 \\
\hline \multirow[t]{2}{*}{ Previous use of animal manure } & Yes & 53 & 12 & 22.64 & 11.11 \\
\hline & No & 55 & 6 & 10.91 & 5.55 \\
\hline \multirow[t]{2}{*}{ Previous use of other fertilizer types } & Yes & 51 & 35 & 68.63 & 32.41 \\
\hline & No & 57 & 18 & 31.58 & 16.67 \\
\hline \multirow{2}{*}{$\begin{array}{l}\text { Practice of crops association or } \\
\text { rotation }\end{array}$} & Yes & 49 & 13 & 26.53 & 12.04 \\
\hline & No & 59 & 40 & 67.80 & 37.04 \\
\hline \multirow[t]{2}{*}{ Occupation of managerial position } & Yes & 56 & 40 & 71.43 & 37.04 \\
\hline & No & 52 & 13 & 25.00 & 12.04 \\
\hline \multirow[t]{2}{*}{ Size of farmer's household } & $>10$ persons (large) & 36 & 29 & 80.56 & 26.85 \\
\hline & $\leq 10$ persons $($ small $)$ & 72 & 24 & 33.33 & 22.22 \\
\hline \multirow[t]{2}{*}{ Value of agricultural equipment } & $>100.000$ FCFA (rich) & 36 & 28 & 77.78 & 25.93 \\
\hline & $\leq 100.000$ FCFA (poor) & 72 & 25 & 34.72 & 23.15 \\
\hline
\end{tabular}


Table 3: Odds ratio $[\operatorname{Exp}(\beta)]$ and inverse odds ratio $[1 / \operatorname{Exp}(\beta)]$ of coefficients $(\beta)$ estimated from the logit model for compost adoption in the study area $(\mathrm{N}=108)$.

\begin{tabular}{|c|c|c|c|}
\hline Explanatory variables & $\boldsymbol{\beta}$ & $\operatorname{Exp}(\beta)$ & $1 / \operatorname{Exp}(\beta)$ \\
\hline Age of farmer (in years) & $-0.059^{*}$ & 0.943 & 1.060 \\
\hline Gender of farmer & $0.906^{* *}$ & 2.474 & // \\
\hline Farm size/land area cultivated by farmer (in ha) & $-0.193 * * *$ & 0.824 & 1.214 \\
\hline Farmer's membership in a peasant's association & $0.699 *$ & 2.012 & $/ /$ \\
\hline Farmer's membership in a rural credit system & $0.576^{*}$ & 1.780 & // \\
\hline Farm-to-city's distance (in km) & $-0.307 * *$ & 0.736 & 1.359 \\
\hline Practice of extra-agricultural occupation & $-1.043^{*}$ & 0.352 & 2.841 \\
\hline Frequency of contact with extension agents (per cropping year) & $0.417 * *$ & 1.518 & // \\
\hline \multicolumn{4}{|l|}{ Level of education of farmers } \\
\hline -Illiterate & 1.012 & 2.751 & // \\
\hline -Primary school complete & 2.231 & 9.309 & // \\
\hline -Secondary school attended & $2.906^{* *}$ & 18.284 & // \\
\hline -University attended & $3.924 * *$ & 50.602 & // \\
\hline Practice of animal husbandry & $-0.165^{*}$ & 0.848 & 1.179 \\
\hline Cultivation of vegetables & $0.298^{* *}$ & 1.347 & // \\
\hline Ownership of land property right & $-0.659^{*}$ & 0.517 & 1.934 \\
\hline Use of salarial labour & $0.760 * * *$ & 2.139 & // \\
\hline Psychological opinion on compost efficacy & & & // \\
\hline -Disfavourable & 0.417 & 1.517 & $/ /$ \\
\hline -Neutral & 1.107 & 3.025 & $/ /$ \\
\hline -Favourable & $1.989 * * *$ & 7.308 & $/ /$ \\
\hline Previous use of mineral fertilizer & $0.386^{* * *}$ & 1.471 & // \\
\hline Previous use of animal manure & $0.327 * *$ & 1.387 & // \\
\hline Previous use of other fertilizer types & $0.319^{*}$ & 1.376 & $/ /$ \\
\hline Practice of crops association or rotation & $-0.218^{*}$ & 0.804 & 1.244 \\
\hline Occupation of managerial position & $1.253 *$ & 3.499 & // \\
\hline Size of the farmer's household (in number of persons) & $0.072 * * *$ & 1.075 & // \\
\hline Value of agricultural equipment (in FCFA) & $0.704 * * *$ & 2.022 & $/ /$ \\
\hline
\end{tabular}

\section{DISCUSSION}

Young farmers are more likely to adopt compost

The field survey findings already suggest that among the selected farmers, young persons have the highest compost adoption rate than old ones (Tables 1 and 2). The results from the logit model show a negative significant coefficient for the age variable, thus old farmers are less favourable to compost adoption as compared to the young farmers (Table 3). These results corroborate with the previous findings by Jaza (2005) and Focarfe (2005) according to which, young people are more favourable to compost adoption because they are more ambitious or courageous, strong enough to carry compost and prefer adventurous situations like discovering such a new input. Another study by Nkamleu (1996) conducted conjointly in the rural areas surrounding Bafoussam and Yaoundé (Cameroon) also shows that, young people are more interested to cultivate vegetables and food crops by using compost 
because they are more convinced about the compost productivity as compared to old generations who are weak to carry compost and still have the doubt on the efficacy and advantages by using the compost made from household waste. Hence, to motivate a lot of old farmers to also adopt compost, the government should consider rewarding all aged farmers. In this view, special advantages such as health insurance subsidized by government could be granted to cover various risks for this category of farmers more sensible to diseases from carrying/working with compost.

\section{Male farmers are more likely to adopt compost}

From the field survey results, two out of three farmers selected in the study area are male (Tables 1 and 2). The logit model results also corroborate with the field reality. They show that, the variable "gender of farmer" has a positive significant coefficient implying that, male farmers are more likely to adopt compost as compared to female farmers (Table 3). According to Nkamleu (1996) and Jaza (2005), this can be explained by the fact that compared to women, men generally have more physical strength thus are more powerful to carry or manage heavy and voluminous/bulky inputs like compost. Women in contrary prefer to use mineral fertilizer which is less voluminous and light to carry. Hence, the government should consider subsidizing or rewarding female farmers so as to encourage women who are willing to use compost in their farms.

\section{Farmers with large land area are less likely to adopt compost}

The field survey results indicate a high adoption rate of compost for small parcels of land (Table 2). The logit model results corroborate these findings thus, farmers with large land area are less likely to adopt compost as compared to farmers with small parcels of cultivated land (Table 3). In Table 1 , we also saw that most selected farmers practice their agricultural activities in small parcels of land ( 0.33 ha on average) because of their vicinity to Yaoundé where the population density is too high $(3,802$ inhabitants $/ \mathrm{km}^{2}$ ) and therefore less space is devoted to agricultural activities. Furthermore, compost is still a new input in Cameroon and most farmers prefer to test it firstly in small parcels of land. It is after they realize the high compost productivity, efficacy and usefulness in crop production that they extend its use in large parcels of land (Drechsel and Kunze, 2001; Ngnikam and Tanawa, 2002; Jaza, 2007). Reticent farmers mostly have large land areas because they manage big agricultural projects and prefer to avoid risk by using mineral fertilizer (which they are already convinced on its productivity) rather than compost. Hence, the extension team of the Ministry of Agriculture should advertise compost to the owners of large land areas to whom he should explain the long term efficacy of using compost as compared to mineral fertilizer.

\section{Farmers' integration into rural association or credit system would favour compost adoption}

The field survey results already show a high compost adoption rate for those farmers who are members of a peasant association or rural credit system (Table 2). From the logit model results, the farmers' integration into any peasant association or rural credit system would favour their ability to adopt compost (Table 3). In reality, by adhering into a peasant association, new members/farmers would meet their old colleagues with large experience and necessary arguments to convince them to adopt compost for farming activities. The facility of credit granted at low interest rate to farmers that are members of the same peasant association is another advantage because credit could easily help them to afford the compost cost and its transportation charges (Yecke, 2004; Focarfe, 2005). Furthermore, the integration into a peasant association would help the farmers to 
address the transportation issues of the bulky compost, thus facilitate the group problemsolving and create a common voice to be heard by the local government.

\section{Distant farms are less likely to adopt compost}

From the field survey findings, we already listed the long farm-to-city's distance among the main factors disfavouring the compost adoption by farmers in the study area (Table 2). Moreover, the computed OR of the logit model indicates that, distant farms are less likely to adopt compost than those located closer to the city (Table 3 ). This result is in light with previous findings from Jaza (2005) and Nkamleu (1996) according to which, one of the main factors accounting for lower compost adoption in areas surrounding Yaoundé is the decreasing farm profit due to high transport costs associated with delivering bulky amounts of compost to the more distant farms. Further studies by Jaza and Adamowski (2012) and Ngnikam (2000) indicate that, the more one moves further away from the Yaoundé city-centre, the higher is the transport cost and the lower is the farm profit so that it would not be profitable to deliver compost to farms located beyond an $80 \mathrm{~km}$ radius, a finding which was confirmed by the steadily declining compost shadow price as one moves further away from Yaoundé. Hence, to favour compost adoption by long distant farmers, the government should consider subsidizing part or all of the compost transportation costs.

\section{Farmers with extra-agricultural occupation are less likely to adopt compost}

The field survey and model results already prove that, farmers with extraagricultural occupation are less likely to adopt compost (Tables 2 and 3). This is easily explained by the useless of compost in other sectors apart from farming. As a matter of fact, farmers who experience off-farm activities would not need compost for these activities. Furthermore, in terms of salary earned in Cameroon, one day of labour for spreading compost in a farm worth 1500 FCFA/person which is a small amount as compared to the off-farm sectors where one day of labour is remunerated at higher rates (2500 to $10000 \mathrm{FCFA} /$ person) (Jaza and Adamowski, 2012). Besides its less lucrative nature, people consider the farming as a dirty activity where a lot of painful work takes place in the nature under difficult weather conditions (heavy rainfall, sunshine, wind, etc). For this reason, people who have the chance to have another opportunity outside the farming sector would not hesitate to abandon agriculture (Yecke, 2004; Jaza, 2009). Hence, the government should consider an increase in the wage rate or remuneration of farmers so as to attract most people to work on farms using compost.

Farmers in frequent contact with extension agents are more likely to adopt compost

The field survey and model results indicate that, contrary to non-sensitized ones, those farmers who are frequently in contact with the extension agents are more likely to adopt compost (Tables 2 and 3). As a matter of fact, farmers who regularly meet the extension agents have the opportunity to get explanations and informations on the compost efficacy, productivity, long term effect, transportation issues and solutions or other advantages of using compost for farming activities (Ngambeki et al., 2002; Jaza, 2007). Knowing such advantages would attract them on adopting this input. In contrary, those farmers with none or less contacts with the extension agents would not have the opportunity to know the compost and its advantages in the farming sector; hence they would find no motivation for adopting compost. Therefore, the government is encouraged to continue to send his extension team towards various farmers groups in the field where they would advertize farmers on the adoption of compost. 
Highly educated farmers are more likely to adopt compost

The field survey and model results indicate that the high level of education positively influences the probability of adopting compost (Tables 2 and 3). The explanation is that, educated farmers better understand the role or multitude agronomic benefits of compost use in their farms as well as the techniques of compost application into the land (dosage, spreading, processing/coverage against sunshine, etc.) (Ngambeki et al., 2002; Focarfe, 2005). Hence, apart from occasional training offered to farmers, the government should reform the contents of academic curricula of primary or secondary schools so as to include topics related to agriculture or compost use in farming activities. Doing that, we are sure that graduate students from any primary or secondary school of the country would master the techniques of compost use in the farming sector.

\section{Practice of animal husbandry is a handicap to compost adoption}

The field survey and logit model results indicate that farmers practicing agropastoral activities are less likely to adopt compost as compared to those farmers that are fully specialized in crop production (Tables 2 and 3). Hence, the practice of animal husbandry is a handicap to compost adoption (Ngambeki et al., 2002; Focarfe, 2005; Jaza, 2014). As compost already contains the organic matter like animal manure, the agricultural exploitations which simultaneously breed animal (in conjunction with crop production) would not need supplementary organic matter for the maintenance of their soil fertility. Based on the fact that the organic matter contained in compost or animal manure have similar characteristics, the farmers practising livestock activities would find no need in adopting the compost. Most of the time, those farmers practising agro-pastoral activities would have this advantage that their manure is directed obtaining from their own livestock at no or low cost. Hence, the utilization of the manure from their livestock is cheaper than purchasing compost, so that they would find no need to adopt compost.

Farmers cultivating vegetables are more likely to adopt compost than cash crops producers

As earlier mentioned, the farmers cultivating vegetables as major crops are more likely to adopt compost as compared to those categories of farmers producing the cash crops (Tables 2 and 3). In the study area, it is common to find farmers surrounding Yaoundé to produce vegetables for future consumption in the city of Yaoundé where their demand is very high. According to the agronomic requirements, the vegetables need a lot of water to grow up. Unfortunately, water is a scarce resource in areas surrounding Yaoundé which is characterized by an equatorial climate of Guinean type with moderate precipitations (varying from 1565 to $1600 \mathrm{~mm}$ annually) and two annual dry seasons (Ngambeki et al., 2002; Kuete et al., 2003). However, because compost functions like a sponge by saving water in its organic matter, one of the advantages of using compost in such zone with moderate precipitations is that, this input has a mechanism to store water in such a way that water needed by vegetables to grow up can easily be found in compost (Duane, 2004). Most vegetables could then avoid hydric stress in areas surrounding Yaoundé by being fertilized with compost. Consequently to avoid hydric stress, most producers would prefer cultivating their vegetables by using compost (Jaza, 2014). The cash crops (cocoa, coffee) are not so demanding in water, so there is less argument to use the Yaoundé compost to grow them. In short, there is no need for producers of cash crops to adopt compost around the Yaoundé zones. 
Farmers who rent land are more favorable to compost adoption

The field survey and model results indicate that farmers who rent their land are more likely to adopt compost than those owners of their land (Tables 2 and 3). This unexpected result is in contradiction with a previous study conducted in the villages surrounding Bafoussam (Cameroon) by Nkamleu (1996) who found that, due to the long-term effect of nutrients released from compost, those farmers who permanently own their land would easily adopt compost because the investment made during the first year can be earned for a period of up to three years whereas those farmers who rent their land would avoid the risk to produce with compost because part of their profit would be left unearned. However, this argument does not hold for farmers living around Yaoundé which is a big city i.e. the administrative capital of Cameroon where the very high population density affects the various uses of land in the area (Kuete et al., 2003). So, contrary to Bafoussam, land is scarce in Yaoundé where it is rare to purchase or own a permanent piece of land for farming activities and hence, farmers are obliged to cultivate on rented land. Generally, the landlords around Yaoundé earn more money by renting their land to the producers of vegetables rather than using it permanently for the production of cash crops. The land is usually rented for short term contracts (less than one year) which enable farmers to produce vegetables that need huge amount of compost. Hence, the government should reward the Yaoundé's landlords so as to encourage them to negotiate long term contracts with compost users who need to benefit from the long-term effect of compost use on the rented parcels of land.

Farmers employing salarial labour are more likely to adopt compost

The logit model results suggest that, farmers employing salarial labour are at a 2.939 greater probability of adopting compost than those working with the familial labour
(Table 3). As a matter of fact, the spreading of compost into the land is a quite difficult task because it takes a lot of time and needs many people to do the work (compost is a voluminous/bulky input and needs many persons to carry it while spreading it in the farm). Therefore, farmers who count only on the non-salarial/familial labour are not able to finish the spreading of compost over the expected period of time or before the end of the cropping season (Yecke, 2004; Jaza, 2009). From the field observation, a farmer who is not sure to have enough labour to help him in the spreading of compost into the land would not accept to adopt compost; he would rather prefer to use a substitute fertilizer such as mineral fertilizer which needs less labourers (Ministry of Agriculture, 2003; Yecke, 2004). We therefore recommend to the government to implement a contract system to be signed with salarial workers so as to ensure to the farmers about the availability of labour during the intensive period of the spreading compost into the land.

Farmers with favourable opinion on compost efficacy are more likely to adopt compost

As earlier mentioned, farmers with favourable opinion on compost efficacy are more likely to adopt compost (Table 3). From the field survey results, the adoption rate of compost is $29.63 \%, 12.04 \%$ and $7.41 \%$ for farmers with favourable, neutral and disfavourable opinion on compost efficacy, respectively (Table 2). These results corroborate with previous findings by Yecke (2004) and Jaza (2005) according to which, $52 \%$ of farmers living nearby Yaoundé are favourable to the use of compost because of its high productivity and efficacy for crop production. The same study reveals that, 3\% of farmers have a disfavourable opinion on compost efficacy so that they would never use this input even if it is offered "free of charge". The remaining $45 \%$ of farmers from that study who have a neutral opinion are willing to 
change their compost adoption's opinion from neutral to favourable if the government decides to offer the compost and its transportation cost "free of charge" or at a subsidized rate of at least $77 \%$ (Ngambeki et al., 2002; Jaza, 2005). Hence, the government should consider subsidizing the compost price or its transport cost or let the extension team from the Ministry of Agriculture to multiply contacts with farmers so as to convince them on the compost efficacy (Ministry of Agriculture, 2003). This would in the long term help those farmers to easily adopt compost.

\section{Farmers with previous fertilization experience are more likely to adopt compost}

As earlier mentioned, farmers with previous fertilization experience are more likely to adopt compost as compared to the category of farmers that never uses fertilizer in the past (Tables 2 and 3). This could be explained by the fact that, previous fertilizer users are already convinced on the necessity of fertilizer application which in Cameroon, has contributed to an increase of food crops yield by 54\% (Ministry of Agriculture, 2003; Focarfe, 2005; Jaza, 2005). Hence, any farmer who experienced the use of fertilizer for at least one time would like to continue using it because he would realize the increase in the yield of his crops or the improvement in the properties of his soil thanks to the fertilizer application. Hence, the government should give more chance to those farmers with none fertilization experience by awarding them credits to purchase compost.

\section{Farmers practicing crops association or rotation are less likely to adopt compost}

Results of logit model indicate that farmers who practise mono-cropping are more likely to adopt compost as compared to the category of farmers who planted several crops in association or rotation (Tables 2 and 3). It is proved in the agronomic literature that crops association or rotation play a role similar to that of compost use because the association or rotation of several crops also prevents plant diseases through microorganisms control over several cycles of production. Hence, farmers who practise crops association or rotation would be reticent to adopt compost because they do not face any problem in terms of plant infestation by diseases, degradation of soil structure/texture and soil erosion (Ministry of Agriculture, 2003). In opposite to the latter category, the other farmers who practise mono-cropping would judge necessary to adopt compost because this input would be their sole source of organic constituents necessary to protect their plants and maintain a good equilibrium between soil and plants (Drechsel and Kunze, 2001; Duane, 2004). In short, if government authorities want to advertise the compost use by large number of farmers, its policies should encourage mono-cropping in replacement of crops association or rotation.

\section{Occupation of managerial position}

From the field survey and model results, farmers with managerial position are more likely to adopt compost as compared to the category of farmers that do not occupy any managerial position (Tables 2 and 3). As a matter of fact, a farmer occupying a managerial position is always the first person to get new information to disseminate to members of his group. $\mathrm{He}$ is the responsible person to represent/decide on the behalf of his group during various consultations in international or national seminars, meetings, workshops, etc where he would gain new knowledge while sharing his experience with other colleagues who would better explain him the advantages of compost use in farming (Nkamleu, 1996; Focarfe, 2005). In short, in order to favour compost adoption, the government policy should appoint several farmers at various positions of responsibility. 


\section{Size of the farmer's household}

As earlier mentioned, farmers with large household size are more likely to adopt compost as compared to the category of farmers with small household size (Tables 2 and 3). We already said that, due to the voluminous/bulky nature of compost, very large amount of this input is needed for crop fertilization hence a lot of people are needed to carry it during the fertilization (Drechsel and Kunze, 2001; Jaza and Adamowski, 2012). Therefore, only households with large size can overcome this challenge which is difficult to achieve for those households with less number of people residing in their house. In the rural areas surrounding Yaoundé, it is common to see a polygamous mariage where a male farmer is married to several wives so as to increase his chance to have many children in his household and therefore to have enough people to work on compost farms (Kuete et al., 2003). Hence, in order to favour the adoption of compost, this system of polygamous union should be encouraged by government authorities.

\section{Value of agricultural equipment}

As earlier mentioned, farmers with high value of agricultural equipment are more likely to adopt compost as compared to farmers with low agricultural equipment value (Tables 2 and 3). In general, the value of agricultural equipment is an appropriate estimation of wealth or welfare of the farmer. The compost being a new input not yet known by everyone, only the wealthiest farmers would have enough mean to attempt its use as compared to poorest farmers who still doubt on the efficacy of this input and do not want to take any risk in spending their money to purchase it for none guaranteed outcome (Ngnikam and Tanawa, 2002; Focarfe, 2005). This then explains the high adoption rate of this input by rich farmers as compared to poor ones. Furthermore, because of its voluminous nature and in order to ensure its fast spreading into the land, compost require special modern equipment such as chisels, tractors, etc which cannot be affordable by poor farmers (especially in a developing country like Cameroon where about $40 \%$ of farmers live below the poverty line) (World Bank, 2014). Hence, in order to favour compost adoption, the government should develop the agricultural mechanization for all categories of farmers.

\section{Conclusion}

The compost adoption by farmers producing crops in regions nearness Yaoundé (Cameroon) depends on various socioeconomic factors. Out of the 21 factors analyzed in this study, the compost adoption rate is higher than non-adoption rate for the following 14 factors: gender of farmer, membership in a peasants association, membership in a rural credit system, contact with extension agents, education of farmer, cultivation of vegetables, use of salarial labour, psychological opinion on compost efficacy, use of mineral fertilizer, animal manure and other fertilizer types, household size, occupation of managerial position, value of agricultural equipment. The latter 14 factors are mostly variables with positive coefficients and odds ratio higher than one in logit model.

However, the percentage of noncompost adopters is higher than compost adopters for the remaining 7 factors which are: age of farmer, farm size, farm-to-city's distance, extra-agricultural occupation, animal husbandry practice, ownership of land property right, practice of crops association or rotation. In most cases, these are variables with negative coefficients and odds ratio lower than one in the logit model.

In short, in order to favour the adoption of compost by large number of farmers, the study recommends to the government authorities to consider subsidizing the compost price, rewarding far located farmers, female farmers, aged farmers and vegetables producers. Its policy should also promote 
peasants association to address the compost transportation issues, subsidize part or all of the compost transportation costs, develop the extension programs of compost to various farmers groups, reform the contents of academic curricula so as to include compost related topics, reward landlords to sign long term contracts with compost producers, reward compost workers at high wage, set up an efficient credit system for compost users, encourage mono-cropping, appoint farmers at managerial positions, encourage polygamous union and develop agricultural mechanization for all categories of farmers, etc.

\section{ACKNOWLEDGEMENTS}

The author wishes to thank the Alexander von Humboldt $(\mathrm{AvH})$ Foundation in Germany for funding this research.

\section{REFERENCES}

Drechsel P, Kunze D. 2001. Waste Composting for Urban and Peri-Urban Agriculture: Closing the Rural-Urban Nutrient Cycle in Sub-Saharan Africa. CABI Publishing: Oxon, United Kingdom.

Duane F. 2004. Using compost to reduce irrigation costs. Biocycle Journal of Composting and Organic Recycling, 45(12): 31-42.

Focarfe. 2005. Collecte autonome des ordures ménagères et compostage dans 10 quartiers de Yaoundé: rapport d'exécution du projet. Coopération Française: Yaoundé, Cameroun.

Gujarati DN. 1995. Basic Econometrics (3 ${ }^{\text {rd }}$ edn). McGraw-Hill: New York, USA.

Jaza FAJ. 2005. The use of compost from household waste in agriculture: economic and environmental analysis in Cameroon. In Farming and Rural Systems Economics (vol 73), Doppler W, Bauer S (eds). Margraf Publishers: Weikersheim, Germany; 1-246.
Jaza FAJ. 2007. The Use of compost for the cultivation of foodstuff crops and vegetables in villages surrounding Yaoundé (Cameroon): descriptive and production function approaches of analysis. Quarterly Journal of International Agriculture, 46(3): 221239.

Jaza FAJ. 2009. The substitution of mineral fertilizers by compost from household waste in Cameroon: economic analysis with a partial equilibrium model. Journal of Waste Management \& Research, 27(3): 207-223.

Jaza FAJ, Adamowski JF. 2012. Application of the Von Thünen model in determining optimal locations to transport compost for crop production outside of Yaoundé, Cameroon. Journal of Human Ecology, 39(2):125-143.

Jaza FAJ. 2014. Application of Coase theorem to analyze the welfare gain and loss in a conflict of herders' damage in croppers' land at the Adamawa region of Cameroon. Quarterly Journal of International Agriculture, 53(1): 1-24.

Kuete M, Elong JG, Dikoume AF. 2003. Bilan Diagnostic de l'Arrondissement de Soa, (Tome 2): Etude de l'Arrondissement de Soa. Centre de Recherche sur les Hautes Terres (CEREHT): Yaoundé, Cameroun.

Ministry of Agriculture. 2003. Marché des engrais: les chiffres et grandes tendances au Cameroun. Terres Fertiles, 3(1): 10-19.

Ndoumbé NH, Ngnikam E, Wethe J. 1995. Le compostage des ordures ménagères: l'expérience du Cameroun après la dévaluation du Franc CFA. Bulletin Africain, 5(1): 4-10.

Ngambeki DS, Deuson RR, Preckel PV. 2002. Integrating livestock into farming systems in Northern Cameroon. Agricultural Systems, 38(2): 319-338.

Ngnikam E. 2000. Evaluation environnementale et économique de 
systèmes de gestion des déchets solides municipaux: analyse du cas de Yaoundé au Cameroun. Thèse de Doctorat. Institut des Sciences Appliquées de Lyon (INSA), Lyon, France, 363 pp.

Ngnikam E, Tanawa E. 2002. Avantages économiques du compostage. Poster à l'atelier de restitution et de capitalisation des résultats de gestion durable et de l'assainissement urbain au Cameroun. Yaoundé, Cameroun, 3-4 Novembre 2003.

Ngnikam EJ, Wethe J, Vermande P. 2005. Une méthode d'évaluation de la production des déchets dans les marchés des villes africaines: l'exemple de Douala et Yaoundé au Cameroun. Bulletin Africain, 19(4): 16-25.

Nkamleu NG. 1996. Analyse de l'adoption des déchets urbains dans les exploitations agricoles péri-urbaines: cas des ordures ménagères de Yaoundé et Bafoussam (Cameroun). Thèse de Doctorat $\mathrm{du} 3^{\mathrm{e}}$ cycle. Université de Cocody, Faculté des Sciences Economiques et de Gestion, Abidjan, Côte d'Ivoire, $178 \mathrm{p}$.

Terrell GR. 1999. Mathematical Statistics: $a$ Unified Introduction. Springer-Verlag: New York, USA.

Wooldridge JM. 2009. Introductory Econometrics: a Modern Approach. McGraw-Hill: New York, USA.

World Bank. 2014. World Development Indicators Database, 2004. http:// www.worldbank.org (07 December 2014).

Yecke MR. 2004. Aspects économiques et financiers de l'emploi du compost comme engrais. Communication au séminaire sur la vulgarisation du compost. Yaoundé, Cameroun, 17-18 Mai 2004. 